\title{
SARS-CoV-2 COVID-19
}

${ }^{1}$ Department of Environmental Medicine, University of Rochester Medical Center,

15 *Correspondence should be addressed to:

16 Irfan Rahman, Ph.D.

17 Department of Environmental Medicine

18 University of Rochester Medical Center

19 Box 850, 601 Elmwood Avenue

20 Rochester 14642, NY, USA

21 Tel: 15852756911

22 E-mail: irfan rahman@urmc.rochester.edu

26 Short running title: Systemic biomarkers of COVID-19 in smokers 
medRxiv preprint doi: https://doi.org/10.1101/2021.01.14.21249836; this version posted January 15, 2021. The copyright holder for this preprint (which was not certified by peer review) is the author/funder, who has granted medRxiv a license to display the preprint in perpetuity.

\section{Abstract}

28 Background: Tobacco smoking is known to be involved in the pathogenesis of several

29 cardiopulmonary diseases, and smokers are susceptible to infectious agents. However,

30 the progression of lung injury based on COVID-19 susceptibility and severity amongst

31 smokers and those with pre-existing pulmonary diseases is not known. We determined

32 the systemic expression and activity of COVID-19 related proteins, cytokine/chemokines,

33 and lipid mediators (lipidomics) amongst COVID-19 patients with and without a history of

34 smoking with a view to define biomarkers.

35 Methods: We obtained serum from COVID-19 positive and COVID-19 recovered patients

36 with and without a history of smoking. We conducted a Luminex multiplex assay (cytokine

37 levels), LC/MS (eicosanoids or oxylipin panel) and enzymatic activity assays on the serum

38 samples to study the systemic changes in COVID-19 patients.

39 Results: On comparing the cytokine profiles among COVID-19 positive and COVID-19

40 negative patients, we found a significant upregulation in the production of pro-

41 inflammatory cytokines like IL-1 $\alpha$, IL-8, IL-2, VEGF and IL-10 in COVID-19 positive

42 patients as compared to the respective controls. Interestingly, smoking history resulted in

43 further augmentation of the release of some hyper-inflammatory cytokines, like IFN- $\gamma$,

44 Eotaxin, MCP-1 and IL-9 amongst COVID-19 positive patients. The enzymatic activity for

45 ACE2, the binding partner for SARS-CoV2 virus in the host cell, was found to be

46 significantly increased in the serum of patients with a smoking history compared to the

47 serum collected from the non-smoking controls. Similarly to our cytokine analysis, our

48 measurement of serum Furin levels was also affected by the patient's smoking history, in

49 which we reported a substantial rise in serum Furin levels of COVID-19 patients. The 
50 analysis of lipid mediators revealed a distinct signature amongst the COVID-19 positive

51 versus recovered subjects in $\mathrm{PGF}_{2 \alpha}$, HETEs, LXA 4 and $\mathrm{LTB}_{4}$ levels. However, we did not

52 find any changes in the levels of any lipid mediators based on the smoking history of the

53 patients. Overall, our results point towards distinct systemic signatures amongst COVID-

5419 positive patients. We also show that smoking adversely affects the systemic levels of

55 inflammatory markers and COVID-19 related proteins, thus suggesting that COVID-19

56 infection may have severe outcomes amongst smokers which is reflected systemically.

57

58 Keywords: COVID-19, ACE2, SARS-CoV-2, inflammation, Smoking 
medRxiv preprint doi: https://doi.org/10.1101/2021.01.14.21249836; this version posted January 15, 2021. The copyright holder for this preprint (which was not certified by peer review) is the author/funder, who has granted medRxiv a license to display the preprint in perpetuity.

\section{Introduction}

72 The current pandemic of coronavirus disease 2019 (COVID-19) has emerged as a major

73 public health threat worldwide. Viral pneumonia and acute respiratory failure are the most

74 common clinical manifestations of severe COVID-19, featuring fever, cough, hypoxemia,

75 dyspnea, and bilateral infiltrates on chest radiography (1). ACE2 (angiotensin converting

76 enzyme 2) receptor is the viral binding site for the SARS-CoV2 in human. ACE2 is

77 abundantly expressed in the lung epithelium, specifically type II pneumocytes, goblet

78 cells, nasal epithelial/ciliated cells and oral mucosal cells (2-4). Under normal

79 circumstances, ACE2 converts angiotensin 2 to metabolites, many of which exert

80 vasodilatory properties. However, since the onset of this pandemic, ACE2 is being widely

81 studied in the context of COVID-19. In this regard, it is still mostly unknown the specific

82 nature of the change in ACE2 induced by SARS-CoV-2 infection, whether it's the

83 modulation of ACE-2 activity or its expression levels that have significance in affecting

84 COVID-19 disease outcome.

86 With continual spreading of the virus and reports of a novel, mutant strain causing further

87 alarm and panic, questions regarding COVID19 risk-factors have become even more

88 urgent and a cause for concern. While old age, heart disease and diabetes are the

89 universally accepted risk factors for COVID19, there are many other factors that are

90 subject to debate and require empirical analysis. One such risk factor is smoking. While

91 initial reports on COVID-19 risk factors have indicated little to no risk amongst smokers,

92 recent data suggests otherwise $(2,5)$. A meta-analysis of 15 studies with a total of 2473

93 confirmed COVID-19 patients reported that COPD patients $(63 \%$ vs 33.4 in people 
94 without COPD) and current smokers (22\%) are at a higher risk of severity and mortality

95 due to COVID-19 compared to disease-free and non-smoking individuals respectively

96 (95\% confidence interval) $(6,7)$. Similar findings were reported by Patanavanich et al

97 (2020), whose research suggested that smoking nearly doubles the rate of COVID-19

98 progression amongst patients (8). Despite these findings, the exact pathogenesis of

99 COVID-19 and the clinical features resulting in severe outcomes amongst smokers is 100 largely unexplored.

101

102 In consideration of this lack of research and the growing call of concern for further

103 research into COVID-19 risk-factors, we investigated whether a variation in systemic

104 markers for inflammation and COVID-19 infection existed between smokers and non-

105 smokers. We also studied the gender-based differences in the expression and activity of

106 COVID-19 related proteins (ACE2 and Furin) to understand the progression of the

107 disease amongst both sexes. Evidence from previous literature has suggested

108 upregulated levels of ACE-2 in the lungs of smokers. However, there is no evidence

109 correlating this increased expression to COVID-19 disease development and severity.

110 Our study investigates the relationship between COVID-19 biomarkers and disease

111 severity and shows a marked increase in the inflammatory spillover amongst COVID-19

112 positive patients with a smoking history compared to controls. We were also able to show

113 a pronounced increase in cytokine/chemokine and Furin ( $\mathrm{S} 1 / \mathrm{S} 2$ cleavage protein) levels

114 in serum of COVID-19 positive patients compared to the COVID-19 recovered controls.

115 Lipid profiling further showed noticeable increases in the levels of Prostaglandin 
medRxiv preprint doi: https://doi.org/10.1101/2021.01.14.21249836; this version posted January 15, 2021. The copyright holder for this preprint (which was not certified by peer review) is the author/funder, who has granted medRxiv a license to display the preprint in perpetuity.

All rights reserved. No reuse allowed without permission.

$1162 \alpha$, leukotrienes $B_{4}$, lipoxin $A_{4}$ and 15- Hydroxyeicosatetraenoic acid in serum collected

117 from COVID-19 positive patients.

118

\section{Materials and Methods}

\section{Ethics/Approval}

121 All the procedures performed in this study comply with the protocols approved by the

122 Institutional Review Board /Research Subject Review Board (RSRB) committee at the

123 University of Rochester Medical Center, Rochester, NY with an approval number

124 CR00002635. The patient samples and information used in this study were procured from

125 a commercial provider- BiolVT (Westbury, NY, USA). All the laboratory procedures were

126 performed in accordance with the regulations specified by the BSL2+ level of containment

127 for Clinical and Research Safety.

128 Human study protocol: Yes; Animal study protocol: None; Institutional biosafety

129 approvals: Yes. The University of Rochester Institutional Biosafety Committee approved

130 the study (study approval number: Rahman/102054/09-167/07-186; identification code:

$131 \quad 07-186)$

\section{Human Blood serum collection}

133 Sera from COVID-19 positive and COVID-19 recovered patients were obtained from

134 BiolVT (Westbury, NY, USA). The patient population was categorized based on smoking

135 status; both current and previous smokers were considered 'Smokers' for subsequent

136 analyses. The characteristics of the study subjects used for the experiments are

137 presented in Table 1. In this study, the results obtained from the sera of the COVID-19

138 recovered patient group are considered equivalent to COVID-19 negative patients. 
Assessment of pro-inflammatory mediators in blood sera using Luminex multiplex

142 The levels of pro-inflammatory cytokines/chemokines like MCP-1, IL-8, IFN- $\gamma$, TNF- $\alpha$ and

$143 \quad$ IL-7 in the sera were measured by Luminex multiplex assay using Bio-Plex Pro ${ }^{\mathrm{TM}}$ Human

144 cytokine 27-plex assay (Cat\#M500KCAFOY, BIO-RAD, Hercules, CA) as per

145 manufacturer's directions. Blood plasma was diluted two-folds and the levels of 27 pro-

146 inflammatory mediators (expressed as pg/ml) were measured using Luminex FlexMap3D

147 system (Luminex, Austin, TX).

148 Assessment of Furin levels using ELISA

149 To determine the level of Furin in sera collected from COVID-19 positive and negative 150 patients, we employed Human Furin ELISA kit (Cat \#: ab113322, Abcam, Cambridge, $151 \mathrm{MA}$ ) as per the manufacturer's protocol. Colorimetric detection was performed at $450 \mathrm{~nm}$ 152 using Cytation 5 microplate reader (BioTek Instruments, Inc. Winooski, VT). Furin levels 153 were expressed as $\mathrm{pg} / \mathrm{ml}$.

\section{Assessment of ACE2 Activity}

156 We utilized the ACE2 Activity Assay kit (Cat \#: K897 BioVision, Milpitas, CA, USA) to

157 determine the ACE2 activity in the human serum samples. The assay was performed as 158 per the manufacturer's instructions. In brief, serum samples were lysed through the 159 addition of equal volumes of ACE2 Lysis Buffer and ACE2 Assay Buffer. The lysed serum 160 samples, in addition to the appropriate standards and controls (positive, negative, and 161 background), were then added to a 96-well plate. After that, 50 ul of ACE2 substrate was 
162 added to both sample and control wells, and subsequently, fluorescence was measured

163 at an excitation maximum of $320 \mathrm{~nm}$ and an emission maximum of $420 \mathrm{~nm}$ using Cytation

1645 microplate reader (BioTek Instruments, Inc. Winooski, VT). Total protein content per

165 sample was determined using the Bradford protein assay kit (Thermo Fisher, Waltham,

$166 \mathrm{MA})$. Sample ACE2 activity for each sample was calculated using the following formula:

168 where, $\mathrm{B}=$ Released MCA (cleaved product of ACE2 substrate) in Sample based on

169 standard curve slope, $\Delta \mathrm{T}=$ Reaction time (in min), $\mathrm{P}=$ Sample used (in $\mathrm{mg}$ ), and $\mathrm{D}=$ 170 Sample Dilution factor.

\section{Determination of Serum Eicosanoid/Oxylipins levels through Lipidomic Analysis}

172 Serum eicosanoid/oxylipin profiling was outsourced to and performed by Cayman

173 Chemical (Ann Arbor, MI). Lipid profiling was done using ultraperformance liquid

174 chromatography in tandem with mass spectroscopy (UPLC-MS/MS). Lipidomes were

175 prepared using serum from six different patients from each group.

176 Nomenclature: The abbreviations used for various classes of lipids include the following:

177 6-keto PGF1 $\alpha$ : 6-keto Prostaglandin F1a, TXB2: Thomboxane B2, PGF2a: Prostaglandin

$178 \mathrm{~F}_{2 \alpha}$, PGE2: Prostaglandin $\mathrm{E}_{2}$, 12-HHTrE: 12-Hyrdoxyheptadecatrenoic acid, LTB4:

179 Leukotriene $\mathrm{B}_{4}$, LXA4: Lipoxin A4, HETE: Hydroxyeicosatrtraenoic acid, EET:

180 epoxyeicosatrienoic acid, HODE:Hydroxyoctadecadienoic acid and HDHA: Hydroxy

181 Docosahexaenoic Acid.

182 Lipid extraction: Lipid extraction from the serum samples was performed by protein 183 precipitation followed by solid-phase extraction (SPE). Protein precipitation was 
184 performed by addition of $50 \mu \mathrm{L} \mathrm{H} 2 \mathrm{O}$ : Acetonitrile solution to each sample. Thereafter, 185 SPE was performed using Strata-X cartridges (33 $\mu \mathrm{m}, 200 \mathrm{mg} / 10 \mathrm{~mL}$; Phenomenex, PA).

186 The extracted lipids were finally dissolved in $100 \mu \mathrm{L}$ water/acetonitrile 60:40 (v:v) solution.

187 To prepare the calibration curves, a mixture of the 20 calibration standards was prepared 188 in methanol.

189 UPLC-MS/MS: 10 ul of calibration standards and samples was added to Kinetex (2.6 $\mu \mathrm{m}$ 190 C18 $100 \AA$ 100x2.1 mm, Phenomenex OOD-4462-AN) column and Reverse phase liquid 191 chromatography (LC) using Sciex ExionLC Integrated System was used for lipid 192 separation. The lipid quantification in the samples was performed using Sciex $6500+$. The

193 total amount of eicosanoids present in each sample was determined using MultiQuant 194 software (Sciex). The lipid abundance ratios were calculated in terms of log base 2-fold 195 change and plotted as a heat map.

\section{Statistical Analyses}

197 All statistical calculations were performed using GraphPad Prism 8.0. Data is expressed 198 as mean \pm SE. Pairwise comparisons were done using unpaired Student's t-test.

199 Differences were considered statistically significant at ${ }^{*} p<0.05,{ }^{* *} p<0.01$, and ${ }^{* * *} p<$ $200 \quad 0.001$ when compared with respective controls.

\section{Results}

\section{ACE-2 activity varies as function of smoking history among COVID-19 patients}

205 Since in humans, ACE2 binds to the SARS-CoV2 spike protein, we investigated changes

207 found a significantly higher ACE2 activity in serum from COVID-19 negative patients 208 compared to serum from COVID19 positive patients. (Fig 1a). This could have occurred 
209 as in this study the COVID-19 negative patient sera actually belong to COVID-19

210 recovered patient group. As expected, after repeating these experiments on blood plasma

211 samples from COVID-19 positive and healthy subjects, we found a significant increase in

212 ACE2 activity in the COVID-19 positive samples compared to healthy controls (data not

213 shown).

214

215 However, it was interesting to find a significant increase in ACE2 activity in serological

216 samples from COVID-19 patients (current and recovered) with a smoking history as

217 compared to non-smokers (Fig 1b). In fact, ACE2 activity was found to be more

218 pronounced among male patients compared to females (Fig 1c). Our results show that

219 age and smoking status play a crucial role in governing the COVID-19 related enzyme 220 activity in human subjects, thereby affecting the disease pathogenesis amongst

221 individuals.

223 Smoking Upregulates Furin Expression in serological samples from COVID-19

\section{4 patients}

226 Another key to understanding COVID-19 virulence as a function of susceptibility to viral

227 entry is analyzing changes in Furin levels. Unlike other Coronaviruses, SARS-CoV-2 has

228 a lessened dependence on target host cell proteases and depends more on proprotein

229 convertase Furin for its viral entry. Based on this, we measured Furin-levels in patient

230 sera from COVID-19-positive and COVID-19 negative (COVID-19 recovered) groups

231 using ELISA. We observed a marked increase in the serum Furin levels $(p=0.083)$ in 
232 COVID-19 positive patients as compared to controls (Fig 2a). A significant upregulation

233 of Furin levels was noted among smokers compared to non-smokers among sera

234 collected from COVID-positive (current and previous) patients (Fig 2b). Similarly,

235 although not significant, Furin levels among male patients were elevated compared to

236 females; this suggests gender-based variations in the Furin expression on SARS-CoV2

237 infection. (Fig 2c).

238

239 Infection with SARS-CoV-2 upregulates pro-inflammatory cytokine expression in 240 smokers

242 It is well known that the exacerbation of the COVID-19 symptoms is associated with an 243 increased expression of pro-inflammatory mediators. Given this, we analyzed the 244 expression of 27 cytokines/chemokines in the serum samples from, COVID-19-positive 245 and COVID-19-negative (recovered) patient population using Luminex multiplex assay. 246 Our results showed significant increases in the levels of IL-8, IL-10, IL-2, VEGF and IL$2471 \alpha(p=0.0616)$ in COVID-19 positive patient sera compared to healthy controls (Fig 3).

248 Parameters such as, IL-5, GM-CSF, IL-12(p70), and IL-15 were undetected in the patient 249 sera from diseased and normal subjects.

251 Intriguingly, when analyzing cytokine/chemokine levels in patient sera based on smoking 252 status, a unique trend emerged. We noted a substantial increase in the production of 253 pro-inflammatory markers like, IFN- $\gamma(\mathrm{p}=0.0836)$, MCP-1 and Eotaxin in the COVID-19 254 positive patient sera who had a smoking history compared to the non-smoking controls. 
medRxiv preprint doi: https://doi.org/10.1101/2021.01.14.21249836; this version posted January 15, 2021. The copyright holder for this preprint (which was not certified by peer review) is the author/funder, who has granted medRxiv a license to display the preprint in perpetuity.

All rights reserved. No reuse allowed without permission.

255 Furthermore, we found a moderate increase in the levels of IL-9 $(p=0.0991)$ amongst

256 smokers infected with COVID 19compared to non-smokers (Fig 4). These results support

257 our hypothesis and further elucidate the role smoking has in exacerbating both disease

258 severity and outcome with regards to SARS-CoV-2 virulence amongst smokers.

259

260 Altered serum lipid profile amongst COVID-19 positive patients

261

262 It is known that infections can induce a variety of alterations in lipid metabolism that 263 4could dampen inflammation or fight infection. Thus, we were next interested in studying

264 the changes in the lipid profiles of patient sera from COVID-19 positive and COVID-19

265 negative groups. Fig 5 depicts a generated heat map which shows alterations in the levels

266 of the 18 most prevalent eicosanoids/oxylipins in sera from COVID-19 positive subjects

267 compared to their respective controls. Most notably, we found noticeable increases in the

268 levels of PGF $2 \alpha$, LTB4, LXA4, 5HETE, and 20-HETE in COVID-19 positive sera. The

269 detailed account of the fold changes in the levels of each of the studied lipids is provided

270 in Table 2.

271

272 Discussion

273 The current pandemic of COVID-19 poses a serious threat to the global health and

274 economy. While the efforts of rolling out an effective vaccine are ongoing, there is panic

275 and uncertainty with regards to the new mutant strain of SARS-CoV2 (9). Amidst of this,

276 it is important to recognize the high-risk populations and the underlying differences in the

277 disease pathogenesis to limit the viral spread in an efficient manner. In this regard, we 
medRxiv preprint doi: https://doi.org/10.1101/2021.01.14.21249836; this version posted January 15, 2021. The copyright holder for this preprint (which was not certified by peer review) is the author/funder, who has granted medRxiv a license to display the preprint in perpetuity.

All rights reserved. No reuse allowed without permission.

278 were interested in understanding the COVID-19 disease severity and progression 279 amongst smokers and investigated the systemic responses against SARS-CoV2 infection

280 in COVID-19 positive and COVID-19 negative patients.

281 We first investigated the ACE2 enzyme activity in the patient serum to determine the role 282 of ACE2 in regulating SARS-CoV2 infection. ACE2 is well-known as the binding receptor 283 for the SARS-CoV2 on host's cell surface and use of ACE inhibitors and ARB blockers in 284 COVID-19 patients is being debated since the start of the pandemic. To our surprise, we 285 found an increased ACE2 activity in our COVID-19 negative patients as compared to 286 COVID-19 positive individuals. It is pertinent to mention here that for this study we are 287 denoting COVID-19 recovered patient sera as COVID-19 negative, which could be the 288 reason for this observation. On determining the ACE2 activity in the plasma samples from 289 COVID-19 positive and healthy individuals from a different cohort we observed a 290 significant increase in ACE2 activity in plasma from COVID-19 positive patients as 291 compared to the normal subjects (Kaur et al., data not shown). This is an interesting 292 find as it shows that ACE2 activity remains persistently elevated even after recovery and 293 might have important implications for future research. Importantly, ACE2 is expressed in 294 various tissues including the heart, kidney, lungs; and can undergo shedding into the 295 blood circulation. Reports suggest that circulating ACE2 activity is indicative of adverse 296 cardiovascular outcomes in patients with hypertension, coronary artery disease and aortic 297 stenosis (10-12). It is also known to have a negative correlation with the glomerular 298 filtration rate in type 1 diabetes $(13,14)$. Considering this, our results suggest 299 dysregulated shedding of active ACE2 even after recovery amongst COVID-19 patients 300 which may have adverse effects in the long run and is subject to further investigation. 
medRxiv preprint doi: https://doi.org/10.1101/2021.01.14.21249836; this version posted January 15, 2021. The copyright holder for this preprint (which was not certified by peer review) is the author/funder, who has granted medRxiv a license to display the preprint in perpetuity.

All rights reserved. No reuse allowed without permission.

301 Interestingly, we found that the ACE2 activity was significantly higher for individuals with

302 a smoking history, thus suggesting that smoking can greatly affect the disease severity

303 and outcomes amongst COVID-19 patients. As has been reported previously (15), our

304 data also shows gender-based upregulation of ACE2 activity amongst males as

305 compared to females. This could correlate to the increased morbidity and mortality

306 amongst male patients and must be interesting to study in future.

307

308 We next studied the levels of Furin proteases in the sera of COVID-19 positive and

309 COVID-19 negative patients. Furin enables the cleavage of S-protein thus facilitating viral

310 cell entry into the host (16). Evidence suggests that furin cleavage plays a potent role in

311 the virulence of dengue, HIV and avian flu $(17,18)$. We observed increased levels of

312 serological Furin in COVID-19 positive patients as compared to controls. We further found

313 that the levels of furin was significantly increased amongst smokers which substantiates

314 our hypothesis that smoking is a risk factor for SARS-CoV2 infection.

316 Coinciding with the existing literature (19-21) we also found increased levels of

317 cytokines/chemokines in the patient serum from COVID-19 positive subjects. Additionally,

318 we for the first time, show significant changes in the levels of these pro-inflammatory

319 mediators in COVID-19 positive patients with a smoking history as compared to the non-

320 smoking controls. Upregulation in the factors like IFN- $\gamma, \mathrm{MCP}-1$ and Eotaxin points

321 towards increased severity of the disease amongst the smokers. Of note, we also found

322 some changes in the lipid profiles of COVID-19 positive and COVID-19 negative patients.

323 Viral infections are known to cause changes in lipid metabolism and play a crucial role in 
324 regulating innate and adaptive immune responses. Amongst the lipids that showed

325 marked increase in COVID-19 positive patients were $\mathrm{PGF}_{2 \alpha}, \mathrm{LTB}_{4}, \mathrm{LXA}_{4}, 15-\mathrm{HETE}$ and

326 20-HETE. Of these, $\mathrm{PGF}_{2 \alpha}$, $\mathrm{LTB}_{4}$ and15-HETE are indicative of bronchoconstriction and

327 lung injury (22-24).

329 Overall, our results show evidence of inflammatory spill-over in COVID-19 positive 330 patients which is shown to be aggravated in patients who smoke. Pulmonary conditions

331 like COPD and smoking-induced lung injury are known to cause such spillovers into the

332 systemic circulation $(25,26)$. Thus, it will be important to develop these inflammatory and

333 lipid mediators as biomarkers to ascertain disease severity amongst COVID-19 patients

334 to provide rapid and effective care for better recovery. Though we have not discussed

335 here but vaping population might be yet another population group that may suffer from

336 severe outcomes in event of a SARS-CoV2 infection. Previous work by our group has

337 shown gender-based variation in the ACE2 expression in lung tissues from C57BI/6J mice

338 exposed to e-cigarette (e-cig) aerosols (27). E-cig use has been associated with loss of

339 lipid homeostasis eventually leading to pulmonary toxicity and lung injury $(28,29)$. Hence

340 it is important to study the disease progress and pathogenesis in this patient population

341 in smokers and vapers (e-cigarette users) in the future.

343 Though we were able to show variations in systemic inflammatory and lipid mediators on

344 SARS-CoV2 infection, our study had some limitations. The sample cohort used for this

345 study was relatively smaller and comprised of a relatively homogenous demographics. It

346 is important to conduct these experiments on a larger sample population with a 
347 heterogeneous demographics to deduce better conclusions. Also, we intend to use 348 patient serum from healthy or COVID-19 negative individuals in the future to compare the

349 variations amongst COVID-19 positive, recovered and healthy subjects. The persistently 350 elevated ACE2 activity in the COVID-19 recovered patients provides evidence for a much

351 thorough investigation into the long-term health effects of SARS-CoV2 infection in

352 smokers. Such an exploration is crucial to understand the mechanistic role of intact and 353 circulating ACE2 in COVID-19 and deduce if recombinant ACE2 could develop as a 354 therapy.

356 In conclusion, we show that the systemic ACE2 activity, Furin levels and cytokine release 357 is upregulated amongst COVID-19 patients with a smoking history, thereby rendering 358 them more susceptible to severe symptoms and disease outcomes. We also show that 359 smoking adversely affects the systemic levels of inflammatory markers and COVID-19 360 related proteins, thus suggesting that COVID-19 infection may have severe outcomes 361 amongst smokers which is reflected systemically. We also provide evidence for 362 inflammatory systemic spillover due to COVID-19 which could be crucial in identifying 363 biomarkers or developing future therapies, and/or monitoring therapies in susceptible 364 population.

\section{List of Abbreviations}

367 COVID-19: Coronavirus Disease-2019

ACE2: Angiotensin converting Enzyme 2

GM-CSF: Granulocyte-macrophage Colony stimulating Factor 
medRxiv preprint doi: https://doi.org/10.1101/2021.01.14.21249836; this version posted January 15, 2021. The copyright holder for this preprint (which was not certified by peer review) is the author/funder, who has granted medRxiv a license to display the preprint in perpetuity.

All rights reserved. No reuse allowed without permission.

HIV: Human Immunodeficiency Virus

COPD: Chronic obstructive pulmonary disease

Acknowledgements: We thank Dr. Shikha Sharma for technical assistance.

Declarations: The authors have declared that no competing interests exist.

Author's Contribution: GK, and SY designed and conducted the experiments, GS, SY, and IR wrote and edited/revised the manuscript. TM analyzed the lipidomic data and edited the manuscript. IR obtained research funding and conceptually designed the overall manuscript.

\section{References}

1. Brosnahan SB, Jonkman AH, Kugler MC, Munger JS, Kaufman DA. COVID-19 and Respiratory System Disorders: Current Knowledge, Future Clinical and Translational Research Questions. Arteriosclerosis, thrombosis, and vascular biology. 2020;40(11):2586-97.

2. Kaur G, Lungarella G, Rahman I. SARS-CoV-2 COVID-19 susceptibility and lung inflammatory storm by smoking and vaping. Journal of inflammation (London, England). 2020;17:21.

3. Ziegler CGK, Allon SJ, Nyquist SK, Mbano IM, Miao VN, Tzouanas CN, et al. SARSCoV-2 Receptor ACE2 Is an Interferon-Stimulated Gene in Human Airway Epithelial Cells and Is Detected in Specific Cell Subsets across Tissues. Cell. 2020;181(5):1016-35.e19.

4. $\quad$ Sungnak W, Huang N, Bécavin C, Berg M, Queen R, Litvinukova M, et al. SARS-CoV-2 entry factors are highly expressed in nasal epithelial cells together with innate immune genes. Nature medicine. 2020;26(5):681-7.

5. Grundy EJ, Suddek T, Filippidis FT, Majeed A, Coronini-Cronberg S. Smoking, SARSCoV-2 and COVID-19: A review of reviews considering implications for public health policy and practice. Tobacco induced diseases. 2020;18:58.

6. Alqahtani JS, Oyelade T, Aldhahir AM, Alghamdi SM, Almehmadi M, Alqahtani AS, et al. Prevalence, Severity and Mortality associated with COPD and Smoking in patients with COVID19: A Rapid Systematic Review and Meta-Analysis. PLoS One. 2020;15(5):e0233147-e. 7. Leung JM, Sin DD. Smoking, ACE-2 and COVID-19: ongoing controversies. The European respiratory journal. 2020;56(1).

8. Patanavanich R, Glantz SA. Smoking Is Associated With COVID-19 Progression: A Meta-analysis. Nicotine \& tobacco research : official journal of the Society for Research on Nicotine and Tobacco. 2020;22(9):1653-6.

9. Baric RS. Emergence of a Highly Fit SARS-CoV-2 Variant. 2020;383(27):2684-6.

10. Ramchand J, Burrell LM. Circulating ACE2: a novel biomarker of cardiovascular risk. Lancet (London, England). 2020;396(10256):937-9. 
medRxiv preprint doi: https://doi.org/10.1101/2021.01.14.21249836; this version posted January 15, 2021. The copyright holder for this preprint (which was not certified by peer review) is the author/funder, who has granted medRxiv a license to display the preprint in perpetuity.

All rights reserved. No reuse allowed without permission.

412 11. Úri K, Fagyas M, Kertész A, Borbély A, Jenei C, Bene O, et al. Circulating ACE2 activity correlates with cardiovascular disease development. Journal of the renin-angiotensinaldosterone system : JRAAS. 2016;17(4).

12. Ramchand J, Patel SK, Srivastava PM, Farouque O, Burrell LM. Elevated plasma angiotensin converting enzyme 2 activity is an independent predictor of major adverse cardiac events in patients with obstructive coronary artery disease. PLoS One. 2018;13(6):e0198144-e. 13. Soro-Paavonen A, Gordin D, Forsblom C, Rosengard-Barlund M, Waden J, Thorn L, et al. Circulating ACE2 activity is increased in patients with type 1 diabetes and vascular complications. Journal of hypertension. 2012;30(2):375-83.

14. Anguiano L, Riera M, Pascual J, Valdivielso JM, Barrios C, Betriu A, et al. Circulating angiotensin converting enzyme 2 activity as a biomarker of silent atherosclerosis in patients with chronic kidney disease. Atherosclerosis. 2016;253:135-43.

15. Sama IE, Ravera A, Santema BT, van Goor H, Ter Maaten JM, Cleland JGF, et al. Circulating plasma concentrations of angiotensin-converting enzyme 2 in men and women with heart failure and effects of renin-angiotensin-aldosterone inhibitors. European heart journal. 2020;41(19):1810-7.

16. Xia S, Lan Q, Su S, Wang X, Xu W, Liu Z, et al. The role of furin cleavage site in SARSCoV-2 spike protein-mediated membrane fusion in the presence or absence of trypsin. Signal transduction and targeted therapy. 2020;5(1):92.

431 17. Fitzgerald K. Furin Protease: From SARS CoV-2 to Anthrax, Diabetes, and 432 Hypertension. The Permanente journal. 2020;24. 18. Walls AC, Park YJ, Tortorici MA, Wall A, McGuire AT, Veesler D. Structure, Function, and Antigenicity of the SARS-CoV-2 Spike Glycoprotein. Cell. 2020;181(2):281-92.e6.

19. Huang C, Wang Y, Li X, Ren L, Zhao J, Hu Y, et al. Clinical features of patients infected with 2019 novel coronavirus in Wuhan, China. Lancet (London, England). 2020;395(10223):497-506.

\section{Hirano T, Murakami M. COVID-19: A New Virus, but a Familiar Receptor and Cytokine} Release Syndrome. Immunity. 2020;52(5):731-3.

21. Mahmudpour M, Roozbeh J, Keshavarz M, Farrokhi S, Nabipour I. COVID-19 cytokine storm: The anger of inflammation. Cytokine. 2020;133:155151.

22. Fish JE, Jameson LS, Albright A, Norman PS. Modulation of the bronchomotor effects of chemical mediators by prostaglandin F2 alpha in asthmatic subjects. The American review of respiratory disease. 1984;130(4):571-4.

23. Martin TR, Pistorese BP, Chi EY, Goodman RB, Matthay MA. Effects of leukotriene B4 in the human lung. Recruitment of neutrophils into the alveolar spaces without a change in protein permeability. The Journal of clinical investigation. 1989;84(5):1609-19.

24. Zhu D, Medhora M, Campbell WB, Spitzbarth N, Baker JE, Jacobs ER. Chronic hypoxia activates lung 15-lipoxygenase, which catalyzes production of 15-HETE and enhances constriction in neonatal rabbit pulmonary arteries. Circulation research. 2003;92(9):992-1000. 25. Liu YY, Chiang CH, Chuang CH, Liu SL, Jheng YH, Ryu JH. Spillover of cytokines and reactive oxygen species in ventilator-induced lung injury associated with inflammation and apoptosis in distal organs. Respiratory care. 2014;59(9):1422-32.

26. Tkacova R. Systemic inflammation in chronic obstructive pulmonary disease: may adipose tissue play a role? Review of the literature and future perspectives. Mediators of inflammation. 2010;2010:585989.

27. Wang Q, Sundar IK, Li D, Lucas JH, Muthumalage T, McDonough SR, et al. E-cigaretteinduced pulmonary inflammation and dysregulated repair are mediated by $\mathrm{nAChR} \alpha 7$ receptor: role of nAChR $\alpha 7$ in SARS-CoV-2 Covid-19 ACE2 receptor regulation. Respiratory research. $460 \quad 2020 ; 21(1): 154$. 
medRxiv preprint doi: https://doi.org/10.1101/2021.01.14.21249836; this version posted January 15, 2021. The copyright holder for this preprint (which was not certified by peer review) is the author/funder, who has granted medRxiv a license to display the preprint in perpetuity.

All rights reserved. No reuse allowed without permission.

461

462

463

464

465

466

467

468

469

470

471

472

473

474

475

476

477

478

479

480

481

482

483

484

485

486

487

488

489

490
28. Madison MC, Landers CT, Gu BH, Chang CY, Tung HY, You R, et al. Electronic cigarettes disrupt lung lipid homeostasis and innate immunity independent of nicotine. The Journal of clinical investigation. 2019;129(10):4290-304.

29. Chand HS, Muthumalage T, Maziak W, Rahman I. Pulmonary Toxicity and the Pathophysiology of Electronic Cigarette, or Vaping Product, Use Associated Lung Injury. Front Pharmacol. 2020;10:1619-.

\section{Tables}

\section{Table 1: Characteristics of COVID-19 positive and negative subjects}

\begin{tabular}{|c|c|c|}
\hline Characteristics & $\begin{array}{c}\text { COVID-19 negative } \\
\text { patients }\end{array}$ & $\begin{array}{c}\text { COVID-19 positive } \\
\text { patients }\end{array}$ \\
\hline $\mathrm{N}$ & 21 & 16 \\
\hline Age (years), mean (SD) & $46.71(13.44)$ & $39.75(14.68)$ \\
\hline Smoker, $\mathrm{n}(\%)$ & $7(33.33)$ & $3(18.75)$ \\
\hline
\end{tabular}



respective fold changes

\begin{tabular}{|c|c|c|}
\hline Analyte & $\begin{array}{c}\text { Log2 fold change } \\
\text { (Cov+ vs CoV-) }\end{array}$ & SD \\
\hline 6-keto PGF $1 a$ & 0.078348 & 0.483034 \\
\hline $\mathrm{TXB}_{2}$ & -0.35068 & 2.271691 \\
\hline $\mathrm{PGF}_{2 a}$ & 0.854693 & 0.877836 \\
\hline $\mathrm{PGE}_{2}$ & 0.685295 & 1.65742 \\
\hline 12-HHTrE & -0.56546 & 1.837558 \\
\hline $\mathrm{LTB}_{4}$ & 1.31646 & 1.100475 \\
\hline $\mathrm{LXA}_{4}$ & 0.112419 & 1.132973 \\
\hline 5-HETE & 1.446217 & 1.704243 \\
\hline 11-HETE & 0.948088 & 1.31254 \\
\hline 12-HETE & 0.473277 & 0.935641 \\
\hline 15-HETE & 0.808158 & 1.10055 \\
\hline 20-HETE & 0.687371 & 0.892525 \\
\hline 5(6)-EET & 1.123827 & 0.756739 \\
\hline 8(9)-EET & -0.15191 & 3.07822 \\
\hline 11(12)-EET & 0.714846 & 1.34743 \\
\hline 9-HODE & -0.83099 & 1.994469 \\
\hline 13-HODE & -0.61875 & 1.361414 \\
\hline 17-HDHA & -0.7935 & 1.346715 \\
\hline
\end{tabular}


Figure 1

(a)

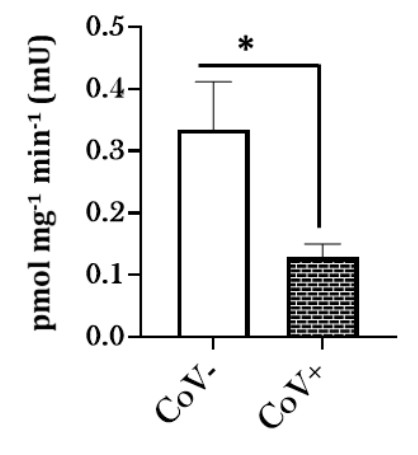

(b)

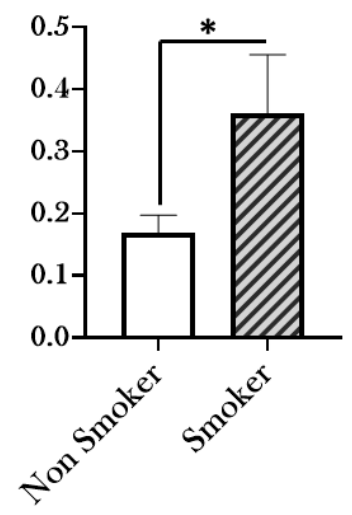

(c)

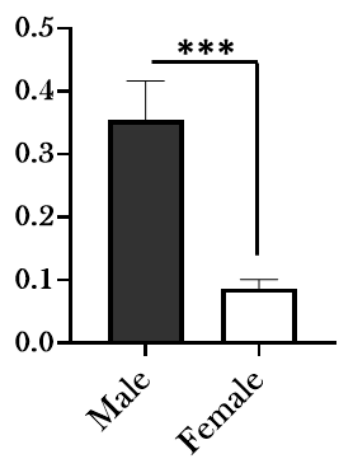

516 Figure 1: Increased ACE2 activity amongst COVID-19 patients with a smoking

517 history. Patient Sera from COVID-19 positive and COVID-19 negative (COVID19

518 recovered) subjects was obtained and the ACE2 activity was quantitatively measured.

519 The obtained results were plotted based on serum Furin levels in (a) COVID-19 negative

520 (COVID-19 recovered) vs COVID-19 positive patients, (b) COVID-19 positive (current or 521 previous) patients with or without a smoking history, and (c) COVID-19 patients based on

522 their gender. Data are shown as mean \pm SEM ( $n=8-15 /$ group). ${ }^{*} p<0.05,{ }^{* * *} p<0.0001$

523 as per Student's t-test for pairwise comparisons. CoV-: COVID-19 negative (COVID-19

524 Recovered), CoV+: COVID-19 positive patients. 
Figure 2

(a)

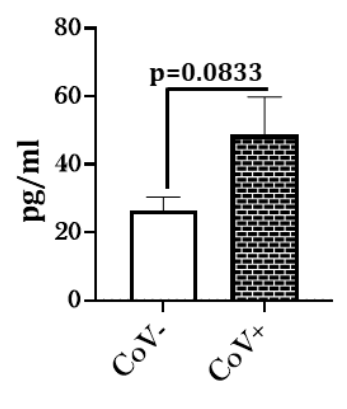

(b)

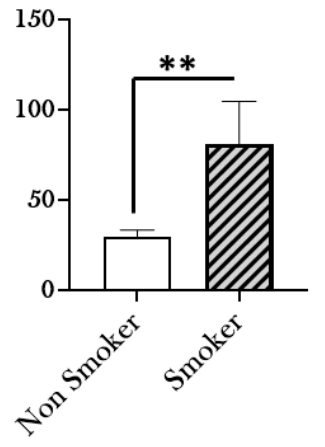

(c)

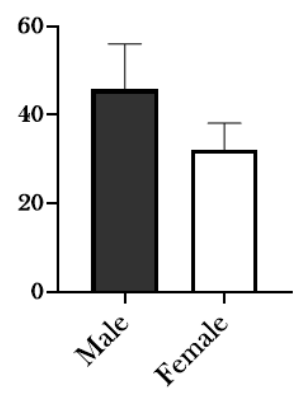

Figure 2: Increased Furin levels amongst COVID-19 patients with a smoking 528 history.

529 Blood serum from COVID-19 positive and COVID-19 negative (COVID-19 recovered) 530 patients were obtained and the Furin levels were quantitatively measured. The obtained

531 results were plotted based on serum Furin levels in (a) COVID-19 negative vs COVID-19 532 positive (COVID-19 recovered) patients, (b) COVID-19 positive patients (current or 533 previous) patients with or without a smoking history, and (c) COVID-19 patients based on 534 their gender. Data are shown as mean \pm SEM ( $n=8-15 /$ group). ${ }^{* *} p<0.001$ as per 535 Student's t-test for pairwise comparisons. CoV-: COVID-19 negative (COVID-19 536 Recovered), CoV+: COVID-19 positive patients 
Figure 3

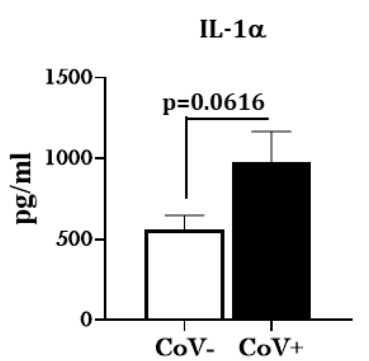

$\mathrm{CoV}-\mathrm{CoV}+$

IL-8

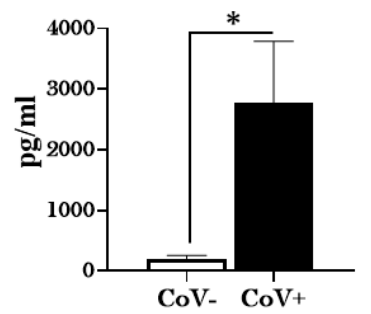

IL-2

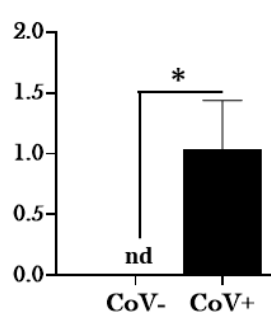

MIP-1 $\alpha$

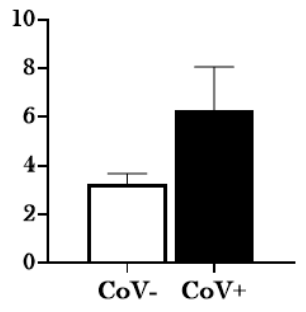

MCP1

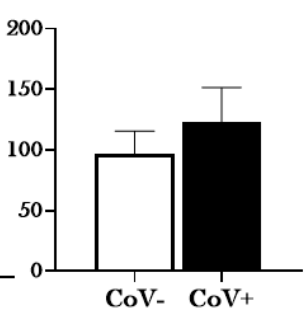

IL-10

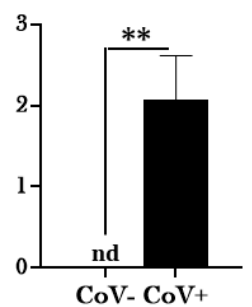

VEGF

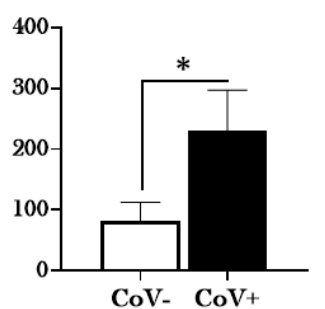

IL-1 $\beta$

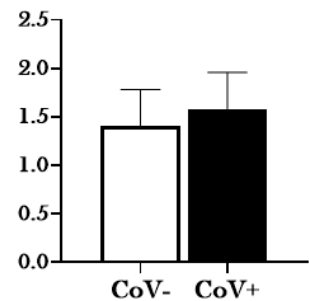

IFN- $\gamma$

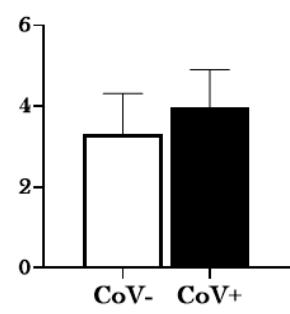

IL-6

538 Figure 3: Elevated cytokine levels in COVID-19 positive patients. Blood serum

539 samples from COVID-19 positive, and COVID-19 negative (COVID-19 recovered)

540 patients were collected and the levels of cytokines/chemokines was assessed with the

541 help of Luminex multiplex assay. The levels of detected cytokines was plotted using

542 GraphPad Prism 8. Data are shown as mean \pm SEM ( $n=10-15 /$ group). * $p<0.05$, **

$543 \mathrm{p}<0.01$; vs CoV- patients as per One-way ANOVA for multiple comparisons. CoV-:

544 COVID-19 negative (COVID-19 recovered), CoV+: COVID-19 positive patients.

545 Cytokines not detected IL-5, GM-CSF, IL-12(p70) and IL-15 
Figure 4
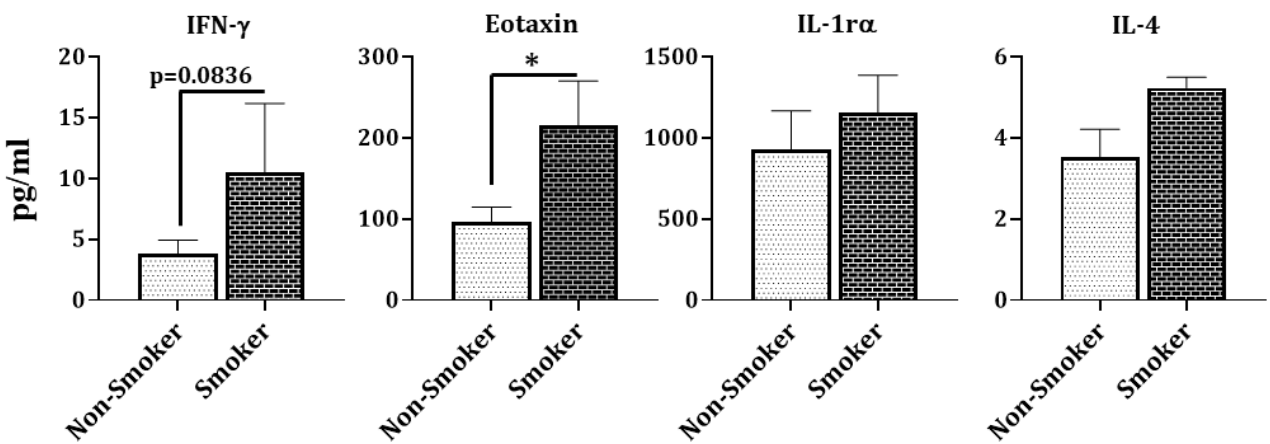

IL-10

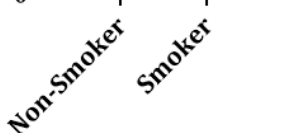

IL-9
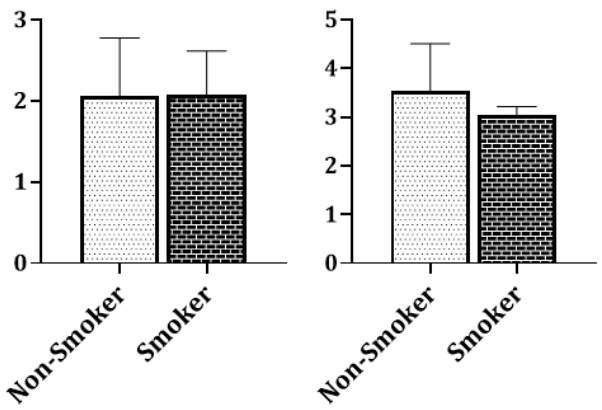

Figure 4: Hyperinflammation in COVID-19 positive patients with a smoking history.

548 Levels of cytokines/chemokines as assessed with the help of Luminex multiplex assay in

549 blood serum samples from COVID-19 positive patients with and without a smoking history

550 (NS: non-smokers and smokers) were collected ( $\mathrm{n}=3-10 /$ group). Data are shown as

551 mean \pm SEM. * $p<0.05$, as per Student's t-test for pairwise comparisons.

Figure 5

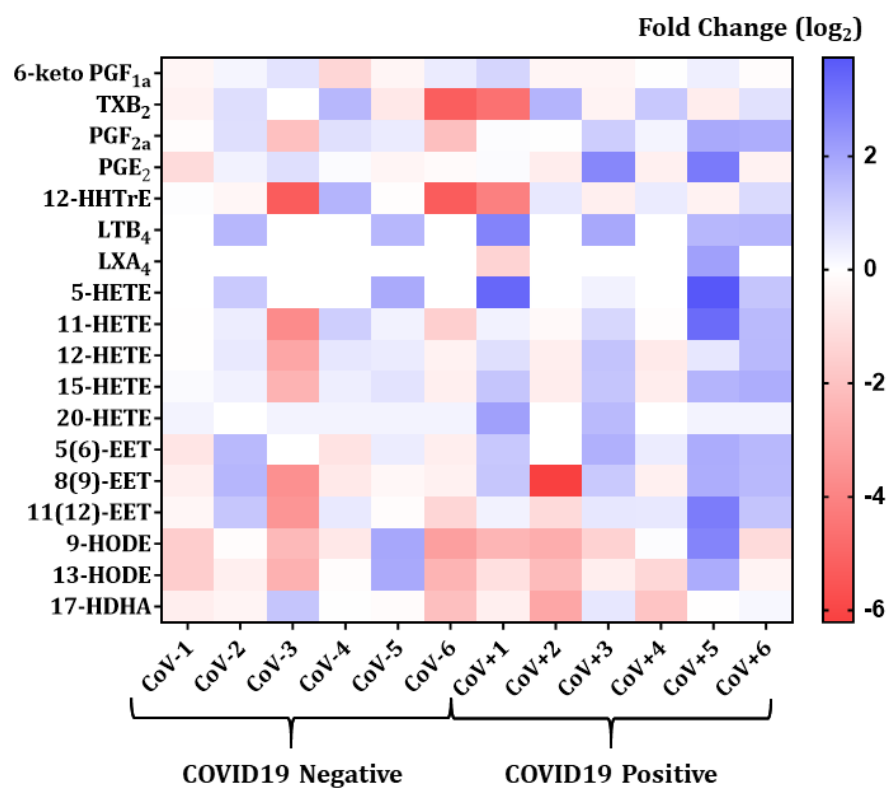


medRxiv preprint doi: https://doi.org/10.1101/2021.01.14.21249836; this version posted January 15, 2021. The copyright holder for this preprint (which was not certified by peer review) is the author/funder, who has granted medRxiv a license to display the preprint in perpetuity.

All rights reserved. No reuse allowed without permission.

553 Figure 5: Heat map of eicosanoid levels in COVID-19 positive and COVID-19 554 negative patient serum. The fold changes in the eicosanoid levels in COVID-19 negative 555 (COVID-19 recovered) patient serum as compared to COVID-19 positive serum. Each 556 horizontal row represents the analyte in a specific lipid class and each vertical column 557 represents the individual sample being tested. Lipid abundance ratios are colored 558 according to the fold changes and the color key indicates the magnitude of log2 fold 559 change. 